University of Nebraska - Lincoln

DigitalCommons@University of Nebraska - Lincoln

Faculty Papers and Publications in Animal

Science

Animal Science Department

1994

\title{
Effect of Fat Source in Receiving Diets and Reduced Nocturnal Temperatures on Commingled Feeder Pig Performance
}

\author{
Michael C. Brumm \\ University of Nebraska-Lincoln, mbrumm@hickorytech.net \\ Ernest R. Peo, Jr. \\ University of Nebraska-Lincoln
}

Follow this and additional works at: https://digitalcommons.unl.edu/animalscifacpub

Part of the Animal Sciences Commons

Brumm, Michael C. and Peo, Jr., Ernest R., "Effect of Fat Source in Receiving Diets and Reduced Nocturnal Temperatures on Commingled Feeder Pig Performance" (1994). Faculty Papers and Publications in Animal Science. 693.

https://digitalcommons.unl.edu/animalscifacpub/693

This Article is brought to you for free and open access by the Animal Science Department at DigitalCommons@University of Nebraska - Lincoln. It has been accepted for inclusion in Faculty Papers and Publications in Animal Science by an authorized administrator of DigitalCommons@University of Nebraska - Lincoln. 


\title{
Effect of Fat Source in Receiving Diets and Reduced Nocturnal Temperatures on Commingled Feeder Pig Performance ${ }^{1,2,3}$
}

\author{
Michael C. Brumm and Ernest R. Peo, Jr. \\ Department of Animal Science, University of Nebraska, \\ Northeast Research and Extension Center, Concord 68728
}

\begin{abstract}
Three experiments using 864 crossbred feeder pigs were conducted to determine the effects of fat sources and a feed flavor in 3-wk receiving diets and a reduced nocturnal temperature regimen on commingled feeder pig performance. In Exp. 1, there was no response to a feed flavor on overall $\mathrm{ADG}$ or ADFI. Commingled pigs offered receiving diets containing $5 \%$ blended vegetable oil (5B) or $5 \%$ tallow (5T) did not differ in overall ADG $(.61, .63 \mathrm{vs} .61 \mathrm{~kg} / \mathrm{d})$ and gain:feed $(.315, .307, .310)$ compared with pigs offered corn-soy diets. In Exp. 2, pigs offered corn-soy receiving diets containing $0,2,4$, or $6 \%(\mathrm{C} 2,2 \mathrm{~B}, 4 \mathrm{~B}$ or $6 \mathrm{~B})$ of a blended vegetable oil had a cubic $(P<.075)$ response for overall ADG (.67, $.68, .66$, and $.69 \mathrm{~kg} / \mathrm{d})$ and linear $(P<.075)$ response for gain:feed $(.309, .307, .316$, and .317$)$. Four percent tallow (4T), compared with $4 \mathrm{~B}$ and $4 \%$ soybean oil
\end{abstract}

(4SO), improved $(P<.1)$ overall ADFI $(2.24$ vs 2.10 $+2.14 \mathrm{~kg} / \mathrm{d}$ ) with no effect on overall ADG. In Exp. 3, $4 \mathrm{~B}$ compared with $4 \mathrm{~T}$ and $4 \%$ yellow grease ( $4 \mathrm{YG}$ ) resulted in a slower $(P<.01)$ overall ADG (.63 vs .68 $+.65 \mathrm{~kg} / \mathrm{d}$ ) with no difference in ADFI or gain:feed. When pooled across Exp. 2 and 3, there was no effect of a reduced nocturnal temperature ( $\mathrm{RNT}$ ) regimen imposed beginning $1 \mathrm{wk}$ after arrival vs a constant temperature control regimen on overall ADG (.65 vs $.67 \mathrm{~kg} / \mathrm{d}$ ) and gain:feed (.303 vs .304). When pooled across Exp. 2 and 3, pigs fed $4 \mathrm{~T}$ had a better $(P<$ .0005 ) overall $\mathrm{ADG}$ than pigs fed $4 \mathrm{~B}(.68 \mathrm{vs} .65 \mathrm{~kg} / \mathrm{d}$ ). These results suggest a differential response on overall performance due to fat sources in commingled feeder pig diets. The results do not support the use of the feed flavor tested or RNT to stimulate performance.

Key Words: Pigs, Fats, Temperature

J. Anim. Sci. 1994. 72:1522-1529

\section{Introduction}

In previous experiments with commingled feeder pigs, dietary energy intake for the 2- to 4-wk after arrival period has been considerably less than NRC (1988) estimated requirements (Brumm et al., 1982, 1987, 1989). Dietary energy intakes for nursery pigs during the last week of several experiments at this research unit during the same time period have also been greater than the intakes of commingled feeder pigs (Brumm et al., 1985; Brumm and Shelton, 1988, 1991). Possible methods to enhance dietary energy intake of feeder pigs include fat additions to the diet to

\footnotetext{
${ }^{1}$ Published as Journal series no. 10280, Agric. Res. Div., University of Nebraska.

${ }^{2}$ Acknowledgement is made to Dennis Forsberg for animal care and Jim Dahlquist for data collection and assistance with statistical analysis.

${ }^{3}$ Supported in part by a grant from the Fats and Proteins Research Foundation, Ft. Myers Beach, FL.

Received March 24, 1993.

Accepted February 27, 1994.
}

increase the caloric density (Pettigrew and Moser, 1991) or reducing the nocturnal temperature below the estimated lower critical temperature to stimulate feed intake (Brumm and Shelton, 1988; Nienaber and Hahn, 1989).

The objectives of the following experiments were to determine the effect of various fat sources in receiving diets, a commercial feed flavor in receiving diets, and a reduced nocturnal temperature regimen on commingled feeder pig performance from purchase to slaughter.

\section{Materials and Methods}

Eight hundred sixty-four crossbred, commingled feeder pigs were used in three experiments conducted at the University of Nebraska's Northeast Research and Extension Center at Concord. Pigs used in all experiments were transported at least $900 \mathrm{~km}$ from auction markets in southern Missouri.

Facilities. In all experiments, pigs were housed in duplicate, mechanically ventilated, partially slatted 
Table 1. Composition of experimental receiving diets (\% as fed)

\begin{tabular}{|c|c|c|c|c|c|c|c|c|c|c|}
\hline \multirow[b]{2}{*}{ Ingredient } & \multicolumn{10}{|c|}{$\operatorname{Diet}^{\mathrm{a}}$} \\
\hline & $\mathrm{C} 1$ & $5 T$ & $5 \mathrm{~B}$ & $\mathrm{C} 2$ & $4 \mathrm{~T}$ & $4 \mathrm{SO}$ & $2 \mathrm{~B}$ & $4 B$ & $6 B$ & $4 \mathrm{YG}$ \\
\hline Corn & $64.45^{\mathrm{e}}$ & $58.90^{\mathrm{e}}$ & $58.90^{\mathrm{e}}$ & 62.95 & 58.45 & 58.45 & 60.70 & 58.45 & 56.45 & 58.45 \\
\hline $44 \mathrm{SBM}$ & 21.25 & 21.75 & 21.75 & 22.50 & 23.00 & 23.00 & 22.75 & 23.00 & 23.00 & 23.00 \\
\hline Oats & 10.00 & 10.00 & 10.00 & 10.00 & 10.00 & 10.00 & 10.00 & 10.00 & 10.00 & 10.00 \\
\hline Limestone & .95 & .90 & .90 & .95 & .95 & .95 & .95 & .95 & .95 & .95 \\
\hline Dicalcium phosphate & .90 & 1.00 & 1.00 & .90 & .90 & .90 & .90 & .90 & .90 & .90 \\
\hline Salt & .40 & .40 & .40 & .40 & .40 & .40 & .40 & .40 & .40 & .40 \\
\hline Vitamin, trace mineral, Se premixes ${ }^{b}$ & 1.05 & 1.05 & 1.05 & 1.05 & 1.05 & 1.05 & 1.05 & 1.05 & 1.05 & 1.05 \\
\hline Tallow & - & 5.00 & - & - & 4.00 & - & - & - & - & - \\
\hline Blended vegetable oil ${ }^{c}$ & - & - & 5.00 & - & - & - & 2.00 & 4.00 & 6.00 & - \\
\hline Soybean oil & - & - & - & - & - & 4.00 & - & - & - & - \\
\hline Yellow grease & - & - & - & - & 一 & - & - & - & - & 4.00 \\
\hline Carbadox premix ${ }^{d}$ & 1.00 & 1.00 & 1.00 & 1.00 & 1.00 & 1.00 & 1.00 & 1.00 & 1.00 & 1.00 \\
\hline Chromic oxide & - & - & 一 & .25 & .25 & .25 & .25 & .25 & .25 & .25 \\
\hline \multicolumn{11}{|c|}{ Calculated analysis (based on NRC, 1988) } \\
\hline Crude protein, \% & 16.0 & 15.8 & 15.8 & 16.4 & 16.3 & 16.3 & 16.4 & 16.3 & 16.1 & 16.3 \\
\hline Lysine, $\%$ & .82 & .82 & .82 & .85 & .85 & .85 & .85 & .85 & .85 & .85 \\
\hline $\mathrm{ME}, \mathrm{kcal} / \mathrm{kg}$ & 3,233 & 3,448 & 3,445 & 3,221 & 3,394 & 3,369 & 3,307 & 3,392 & 3,479 & 3,394 \\
\hline
\end{tabular}

${ }^{\mathrm{a}}$ Diet $=\mathrm{Cl}$, control; $5 \mathrm{~T}, 5 \%$ tallow; $5 \mathrm{~B}, 5 \%$ blended vegetable oil; $\mathrm{C} 2$, control; $4 \mathrm{~T}, 4 \%$ tallow; $4 \mathrm{SO}, 4 \%$ soybean oil; $2 \mathrm{~B}, 2 \%$ blended vegetable oil; $4 \mathrm{~B}, 4 \%$ blended vegetable oil; $6 \mathrm{~B}, 6 \%$ blended vegetable oil; and $4 \mathrm{YG}, 4 \%$ yellow grease.

'brovided the following minerals in the complete diet (ppm): $\mathrm{Zn}, 75 ; \mathrm{Fe}, 88 ; \mathrm{Mn}, 30 ; \mathrm{Cu}, 8.8 ; \mathrm{I}, 1.0$; and Se, 1 ppm. Provided the following vitamins per kilogram of complete diet: vitamin A, 3,300 IU; vitamin D, $550 \mathrm{IU}$; riboflavin, $2.2 \mathrm{mg}$; niacin, $17.6 \mathrm{mg}$; d-pantothenic acid, 9.9 mg; choline chloride, $220 \mathrm{mg}$; vitamin $\mathrm{E}, 11 \mathrm{IU}$; menadione sodium bisulfite, $2.2 \mathrm{mg}$; and vitamin $\mathrm{B}_{12}, .022 \mathrm{mg}$.

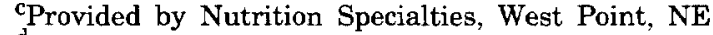

dProvided $55 \mathrm{mg} / \mathrm{kg}$ of carbadox in complete diets.

confinement facilities. Each facility consisted of 12 pens $(1.4 \mathrm{~m} \times 4.9 \mathrm{~m})$ accommodating 12 pigs/pen $(.57$ $\left.\mathrm{m}^{2} / \mathrm{pig}\right)$. Further facility details have been reported by Brumm et al. (1982) and Shelton and Schulte (1982).

Management. Immediately after arrival, all pigs were weighed, sexed, ear tagged, and assigned to experimental treatments on the basis of sex and arrival weight outcome groups.

The experimental receiving diets were limit-fed for $7 \mathrm{~d}$ on the solid floor area of their respective pen according to the recommendation of Brumm et al. (1991). Feed was made available twice daily and was limited to the amount of feed a pen of 12 pigs would consume in a 3- to 4-h period. After $7 \mathrm{~d}$, pigs had ad libitum access to the respective diets. Previous research at this station has demonstrated no effect on 2-wk performance from limit-feeding the 1st wk after arrival vs ad libitum access to feed (Brumm et al., 1989).

After 3 wk of offering the experimental diets, all pigs within an experiment were fed a common $16 \% \mathrm{CP}$ corn-soy based diet containing no oats or added fat. From $57 \mathrm{~kg}$ live weight to slaughter, pigs were offered a $14 \% \mathrm{CP}$ diet. All diets were in meal form. Diets in all experiments contained $55 \mathrm{mg} / \mathrm{kg}$ of carbadox until 34 $\mathrm{kg}$ live weight.

All pigs were weighed weekly for the first 4 wk of each experiment and biweekly thereafter with feed disappearance determined at that time.

Health Treatments and Observations. At arrival, all pigs were injected with Ivermectin (Ivomec, Merck, Rahway, NJ) for control of parasites. Three to four weeks after arrival they were retreated for internal parasites with fenbendazole (Hoechst-Roussel AgriVet, Somerville, NJ). Pigs dying during an experiment were examined for cause of death by a consulting veterinarian.

Experiment 1. A $3 \times 2$ factorial design was used to examine six receiving diets containing no added fat (C1), 5\% tallow (5T), or 5\% of a commercial vegetable oil blend ( $\mathbf{5 B}$ ) (Nutrition Specialties, West Point, NE) and with or without a commercial feed flavor (Super 10 Pig Blend, Feed Flavors, Wheeling, IL) (Table 1). There were two pens per diet combination per barn (block) with two barns used for a total of four pens per diet combination.

Beginning at $34 \mathrm{~kg}$ live weight, all diets contained $44 \mathrm{mg} / \mathrm{kg}$ of lincomycin until $1 \mathrm{wk}$ before slaughter.

Experiments 2 and 3. Two regimens to manage air temperature in the pig zone were employed. The fans and furnace thermostats in the control facility ( CON) were set to maintain a dry-bulb temperature of $23^{\circ} \mathrm{C}$ for the 1st wk after arrival. Thereafter, the air temperature was decreased $1 \mathrm{C} /$ wk until a temperature of $15^{\circ} \mathrm{C}$ was achieved. This temperature was then maintained for the duration of experiment. In the facility with the reduced nocturnal temperature ( RNT), air temperature in the pig zone was maintained the same as CON for the 1st wk after arrival and for $12 \mathrm{~h} / \mathrm{d}(0700$ to 1900$)$ during subsequent weeks. During nighttime hours (1900 to 0700), starting $1 \mathrm{wk}$ after arrival, the thermostat setting for the furnace and ventilation system was reduced $10 \mathrm{C}^{\circ}$ from the daytime setting. At 1900, the spring/fall and 
Table 2. Effect of fat source and feed flavor on feeder pig performance (Exp. 1)

\begin{tabular}{|c|c|c|c|c|c|c|c|}
\hline \multirow[b]{2}{*}{ Item } & \multicolumn{3}{|c|}{ Fat source ${ }^{a}$} & \multirow[b]{2}{*}{ SEM } & \multicolumn{2}{|c|}{ Flavor ${ }^{b}$} & \multirow[b]{2}{*}{ SEM } \\
\hline & $\mathrm{C} 1$ & $5 B$ & $5 \mathrm{~T}$ & & Yes & No & \\
\hline No. of pens & 8 & 8 & 8 & - & 12 & 12 & - \\
\hline \multicolumn{8}{|l|}{ Pig wt, kg } \\
\hline Initial & 20.4 & 20.4 & 20.4 & $<.1$ & 20.4 & 20.4 & $<.1$ \\
\hline $3 \mathrm{wk}$ & 33.3 & 33.9 & 33.2 & .4 & 33.4 & 33.5 & .4 \\
\hline Final & 88.9 & 89.2 & 90.9 & 1.3 & 89.9 & 89.5 & 1.0 \\
\hline \multicolumn{8}{|c|}{ Average daily gain, $\mathrm{kg}$} \\
\hline 0 to $3 \mathrm{wk}$ & .62 & .64 & .61 & .02 & .62 & .62 & .02 \\
\hline 0 to final & .61 & .61 & .63 & .01 & .62 & .62 & .01 \\
\hline \multicolumn{8}{|c|}{ Average daily feed, $\mathrm{kg}$} \\
\hline 0 to $3 \mathrm{wk}$ & 1.32 & 1.30 & 1.31 & .02 & 1.32 & 1.30 & .02 \\
\hline 0 to final $^{\mathrm{c}}$ & 1.98 & 1.95 & 2.05 & .03 & 2.02 & 1.97 & .03 \\
\hline \multicolumn{8}{|l|}{ Gain:feed } \\
\hline 0 to $3 w^{d}$ & .465 & .494 & .462 & .011 & .469 & .479 & .009 \\
\hline 0 to final ${ }^{\mathrm{e}}$ & .310 & .315 & .307 & .004 & .308 & .314 & .003 \\
\hline
\end{tabular}

${ }^{\mathrm{a}} \mathrm{C} 1=$ control; $5 \mathrm{~B}=5 \%$ blended vegetable oil; $5 \mathrm{~T}=5 \%$ tallow.

bsuper 10 pig blend, Feed Flavor, Wheeling, IL.

${ }^{c} 5 \mathrm{~B}$ vs $5 \mathrm{~T}(P<.05)$.

$\mathrm{d}_{5 \mathrm{~B}}$ vs $5 \mathrm{~T}(P<.075)$.

elavor effect $(P<.1)$.

summer fans were turned on, bringing in cooler outside air over the slatted portion of each pen until the desired temperature was achieved. Temperature regulation was achieved by using dual thermostats controlled by a switching-time clock. Temperature treatments were alternated between barns between experiments.

Within temperatures in Exp. 2, the experimental receiving diets investigated included a control diet with no added fat (C2), diets containing 2,4 , or $6 \%$ of the vegetable oil blend that had been fed in Exp. 1 ( $2 B, 4 B, 6 B), 4 \%$ tallow ( $4 T$ ), and $4 \%$ soybean oil (4SO). All diets contained .25\% chromic oxide as an indigestible marker to determine $\mathrm{DM}$ and $\mathrm{N}$ digestibility.

In Exp. 3, receiving diets investigated within temperature regimen included $\mathrm{C} 2$, and diets containing $4 \mathrm{~T}, 4 \mathrm{~B}$, and $4 \%$ choice yellow grease (4YG). Similar to Exp. 2, all diets contained $.25 \%$ chromic oxide.

Fecal samples were collected from three pigs in each pen (two pens per diet per temperature) on $\mathrm{d} 5$, $6,7,12,13$, and 14 after arrival and frozen for $\mathrm{N}$, chromic oxide, and DM analysis (Schürch et al., 1952). Feed samples were taken from each pen at the same time. Dry matter was determined by oven drying at $105^{\circ} \mathrm{C}$ overnight. Nitrogen was determined by the Kjeldahl method using procedures described by AOAC (1990).

From $34 \mathrm{~kg}$ live weight to $57 \mathrm{~kg}$, all diets contained $110 \mathrm{mg} / \mathrm{kg}$ of chlortetracycline, $110 \mathrm{mg} / \mathrm{kg}$ of sulfamethazine, and $55 \mathrm{mg} / \mathrm{kg}$ of penicillin. No feed additive was added to the diets from $57 \mathrm{~kg}$ to slaughter.

Statistical Analysis. The pen of pigs was the experimental unit for statistical analysis.
Experiment 1 was analyzed as a $3 \times 2$ factorial design with diets replicated within each barn (block) with all 2- and 3-way interactions included in the model. Planned orthogonal contrasts compared $\mathrm{C} 1$ vs both fat containing diets $(5 \mathrm{~B}+5 \mathrm{~T})$ and $5 \mathrm{~B}$ vs $5 \mathrm{~T}$.

Experiments 2 and 3 were analyzed separately with diets replicated within temperature. The statistical model included temperature (barn) as the whole plot and diet, temperature $\times$ diet, and weight block within temperature. In Exp. 2, planned orthogonal contrasts were used to test for linear, quadratic, and cubic effects of $\mathrm{C} 2,2 \mathrm{~B}, 4 \mathrm{~B}$, and $6 \mathrm{~B}$. Orthogonal contrasts also were used to test $\mathrm{C} 2$ vs all fat sources $(4 \mathrm{~B}+4 \mathrm{~T}+$ $4 \mathrm{YG}), 4 \mathrm{SO}$ vs $4 \mathrm{~T}+4 \mathrm{YG}$, and $4 \mathrm{~T}$ vs $4 \mathrm{YG}$.

Across Exp. 2 and 3, the C2, 4B, and $4 \mathrm{~T}$ diets were common and used to test RNT vs CON. Because pigs were allocated to weight replicates (light and heavy) within temperature (barn) within experiment, the weight $\times$ temperature interaction was used as the error term to examine for significant temperature effects and the weight $\times$ diet (temperature) interaction was used to examine for significant diet effects across experiments.

All statistical analysis were conducted using the GLM procedures as outlined by SAS (1982).

\section{Results}

Experiment 1. Because there were no interactions of receiving diet fat source and feed flavor addition, only the main effects are presented (Table 2). The inclusion of $5 \%$ tallow $(5 \mathrm{~T})$ or $5 \%$ blended vegetable oil (5B) had no effect on final weight or average daily gain. However, pigs offered $5 \mathrm{~T}$ receiving diets had numeric improvements in overall ADG compared with 
Table 3. Effect of fat sources on feeder pig performance (Exp. 2)

\begin{tabular}{|c|c|c|c|c|c|c|c|c|c|c|}
\hline \multirow[b]{2}{*}{ Item } & \multicolumn{4}{|c|}{ Blended vegetable oil ${ }^{\mathbf{a}}$} & \multirow[b]{2}{*}{ SEM } & \multicolumn{4}{|c|}{$4 \%$ Fat sources ${ }^{a}$} & \multirow[b]{2}{*}{ SEM } \\
\hline & $\mathrm{C} 2$ & $2 \mathrm{~B}$ & 4B & $6 \mathrm{~B}$ & & $\mathrm{C} 2$ & $4 \mathrm{~B}$ & $4 \mathrm{~T}$ & $4 \mathrm{SO}$ & \\
\hline No. of pens & 4 & 4 & 4 & 4 & - & 4 & 4 & 4 & 4 & - \\
\hline \multicolumn{11}{|l|}{ Pig wt, kg } \\
\hline Initial & 19.6 & 19.6 & 19.5 & 19.4 & .1 & 19.6 & 19.5 & 19.5 & 19.6 & .1 \\
\hline $3 \mathrm{wk}$ & 31.0 & 31.3 & 31.5 & 31.8 & .7 & 31.0 & 31.5 & 32.0 & 31.5 & .3 \\
\hline Final $^{b}$ & 94.3 & 95.4 & 93.8 & 97.0 & .7 & 94.3 & 93.8 & 97.5 & 95.5 & 1.4 \\
\hline \multicolumn{11}{|c|}{ Average daily gain, $\mathrm{kg}$} \\
\hline 0 to $3 \mathrm{wk}$ & .54 & .56 & .57 & .59 & .03 & .54 & .57 & .60 & .57 & .02 \\
\hline 0 to final $^{\mathrm{c}}$ & .67 & .68 & .66 & .69 & .01 & .67 & .66 & .70 & .68 & .01 \\
\hline \multicolumn{11}{|c|}{ Average daily feed, $\mathrm{kg}$} \\
\hline 0 to $3 \mathrm{wk}^{\mathrm{d}}$ & 1.20 & 1.19 & 1.17 & 1.21 & .03 & 1.20 & 1.17 & 1.27 & 1.15 & .03 \\
\hline 0 to final $\mathrm{l}^{\mathrm{e}}$ & 2.16 & 2.21 & 2.10 & 2.18 & .03 & 2.16 & 2.10 & 2.24 & 2.14 & .05 \\
\hline \multicolumn{11}{|l|}{ Gain:feed } \\
\hline 0 to $3 \mathrm{wk}^{\mathrm{fg}}$ & .452 & .469 & .491 & .491 & .015 & .452 & .491 & .473 & .492 & .012 \\
\hline 0 to final ${ }^{\text {fh }}$ & .309 & .307 & .316 & .317 & .003 & .309 & .316 & .312 & .316 & .003 \\
\hline
\end{tabular}

${ }^{\mathrm{a}} \mathrm{C} 2=$ control; $2 \mathrm{~B}=2 \%$ blended vegetable oil; $4 \mathrm{~B}=4 \%$ blended vegetable oil; $6 \mathrm{~B}=6 \%$ blended vegetable oil $; 4 \mathrm{~T}=4 \%$ tallow; $4 \mathrm{SO}=4 \%$ soybean oil.

${ }^{b}$ Cubic effect of blended vegetable oil $(P<.05)$.

${ }^{c}$ Cubic effect of blended vegetable oil $(P<.075)$.

$\mathrm{d}_{4 \mathrm{~T}}$ vs $4 \mathrm{~B}+4 \mathrm{SO}(P<.05)$.

$\mathrm{e}_{4 \mathrm{~T}}$ vs $4 \mathrm{~B}+4 \mathrm{SO}(P<.1)$.

finear effect of blended vegetable oil $(P<.075)$

gC2 vs $4 \mathrm{~B}+4 \mathrm{~T}+4 \mathrm{SO}(P<.075)$.

$\mathrm{h}_{\mathrm{C} 2}$ vs $4 \mathrm{~B}+4 \mathrm{~T}+4 \mathrm{SO}(P<.1)$.

C1 or $5 \mathrm{~B}$. This numeric improvement was accompanied by an increase $(P<.05)$ in overall ADFI for the $5 \mathrm{~T}$ pigs compared with the $5 \mathrm{~B}$ pigs. Pigs offered the $5 \mathrm{~B}$ receiving diet had an improved $(P<.075)$ gain:feed for the $3 \mathrm{wk}$ receiving period compared with $5 \mathrm{~T}$, but there was no effect of receiving diet on overall gain: feed.

The addition of a feed flavor to the receiving diet had no effect on daily gain or feed intake for either period reported. Although the addition of a flavor did not affect 3 wk gain:feed, there was an improvement $(P<.1)$ in overall gain:feed for pigs offered receiving diets containing no feed flavor.

Experiment 2. In Exp. 2, the only interaction $(P<$ .05 ) between receiving diet and temperature occurred for the comparison of the $4 \%$ fat additions $(\mathrm{C} 2,4 \mathrm{~T}, 4 \mathrm{~B}$, and $4 \mathrm{SO})$ and temperature for overall gain:feed (.315, $.312, .310, .309$, RNT; $.302, .312, .321$, and $.323 \mathrm{CON}$ for the respective diets). Thus, only the main effects of diet are shown in Table 3 .

The cubic $(P<.075)$ response to increasing amounts of blended vegetable oil on overall ADG suggests an inconsistent response. Increasing the amount of blended vegetable oil in the receiving diet resulted in a linear $(P<.075)$ improvement in gain: feed for the 3 wh after arrival period and overall.

Compared with $\mathrm{C} 2,4 \mathrm{~B}$, or $4 \mathrm{SO}$, the addition of $4 \mathrm{~T}$ resulted in no difference in overall $A D G$. However, ADFI for the 0- to 3 -wk period was improved for the $4 \mathrm{~T}$ vs $4 \mathrm{~B}+4 \mathrm{SO}$ pigs $(P<.05)$ with an improvement $(P<.1)$ noted overall. The addition of any fat source improved $(P<.075)$ gain:feed for the 0 - to 3-wk period. As a result, overall gain:feed were also improved $(P<.1)$.

Experiment 3. There was an interaction between receiving diet and temperature on 21-d pig weight ( $P$ $<.1)$, ADG $(P<.075)$, and ADFI $(P<.005)$ (Table 4). This was primarily due to an increase in ADFI for pigs offered the C2 diet for the RNT vs CON temperature treatments $(1.27 \mathrm{vs} 1.12 \mathrm{~kg} / \mathrm{d})$. No other interactions were significant and the main effects of receiving diet are presented in Table 5 .

The addition of any fat source to the receiving diets improved 3 wk ADG $(P<.05)$ and gain:feed $(P<.01)$ compared with $\mathrm{C} 2$. Overall, commingled feeder pigs offered receiving diets containing a fat source of animal origin ( $\mathrm{T}$ or $\mathrm{YG}$ ) had an improved $(P<.01)$ ADG compared with pigs offered the $B$ fat source.

Experiments 2 and 3. Figure 1 details the temperatures at pig level and outside for the CON and RNT treatments averaged across both experiments. Because of recording equipment problems, no data are presented for CON on wk $7,14,15$, or 16 and RNT on wk 8 . During the first $8 \mathrm{wk}$, the $10 \mathrm{C}^{\circ}$ nighttime cool down was generally achieved within $2 \mathrm{~h}$. Beginning on wk 9 , a combination of warmer outside air temperatures and increasing pig mass meant that the planned for $10 \mathrm{C}^{\circ}$ reduction in temperature did not always occur. However, a 7 to $8 \mathrm{C}^{\circ}$ reduction was recorded every week.

The only interaction $(P<.05)$ between receiving diet and temperature regimen occurred for overall ADG (Table 6). This was due primarily to pigs offered the $\mathrm{C} 2$ diet having a lower $\mathrm{ADG}$ when exposed to RNT than when exposed to CON. 
Table 4. Interaction of temperature and receiving diet on 3-wk pig performance (Exp. 3)

\begin{tabular}{|c|c|c|c|c|c|c|c|c|c|c|}
\hline \multirow[b]{2}{*}{ Item } & \multirow[b]{2}{*}{ Diet: $^{\text {a }}$} & \multicolumn{4}{|c|}{$\mathrm{CON}^{\mathrm{b}}$} & \multicolumn{4}{|c|}{$\mathrm{RNT}^{\mathrm{b}}$} & \multirow[b]{2}{*}{ SEM } \\
\hline & & $\mathrm{C} 2$ & $4 B$ & $4 \mathrm{~T}$ & $4 \mathrm{YG}$ & $\mathrm{C} 2$ & $4 \mathrm{~B}$ & $4 \mathrm{~T}$ & $4 \mathrm{YG}$ & \\
\hline Pig wt 3 wk, $\mathrm{kg}^{\mathrm{cd}}$ & & 30.5 & 32.4 & 32.3 & 32.2 & 32.1 & 32.3 & 32.2 & 31.9 & .4 \\
\hline Average daily gain, $\mathrm{kg}^{\mathrm{de}}$ & & .52 & .61 & .60 & .60 & .60 & .60 & .61 & .59 & .02 \\
\hline Average daily feed, $\mathrm{kg}^{f}$ & & 1.12 & 1.23 & 1.20 & 1.20 & 1.27 & 1.21 & 1.19 & 1.20 & .02 \\
\hline
\end{tabular}

${ }^{\mathrm{a}} \mathrm{C} 2=$ control; $4 \mathrm{~B}=4 \%$ blended vegetable oil; $4 \mathrm{~T}=4 \%$ tallow; $4 \mathrm{YG}=4 \%$ yellow grease.

${ }^{\mathrm{b}} \mathrm{CON}=$ control; RNT $=$ reduced nocturnal temperature beginning $1 \mathrm{wk}$ after arrival.

CTemperature $x \operatorname{diet}(P<.1)$.

${ }^{\mathrm{d}} \mathrm{C} 2$ vs $4 \mathrm{~B}+4 \mathrm{~T}+4 \mathrm{YG}(P<.05)$

eTemperature $x \operatorname{diet}(P<.075)$.

femperature $x \operatorname{diet}(P<.005)$.

Table 5. Effect of fat source on feeder pig performance (Exp. 3)

\begin{tabular}{|c|c|c|c|c|c|}
\hline \multirow[b]{2}{*}{ Item } & \multicolumn{4}{|c|}{ Receiving diet ${ }^{\mathrm{a}}$} & \multirow[b]{2}{*}{ SEM } \\
\hline & $\mathrm{C} 2$ & $4 B$ & $4 \mathrm{~T}$ & $4 \mathrm{YG}$ & \\
\hline No. of pens & 6 & 6 & 6 & 6 & - \\
\hline \multicolumn{6}{|l|}{ Pig wt, kg } \\
\hline Initial & 19.6 & 19.7 & 19.5 & 19.6 & .1 \\
\hline $3 \mathbf{w k}^{\mathbf{b}}$ & 31.3 & 32.4 & 32.2 & 32.1 & .3 \\
\hline Final $^{c}$ & 96.2 & 94.3 & 100.2 & 97.4 & 1.2 \\
\hline \multicolumn{6}{|c|}{ Average daily gain, $\mathrm{kg}$} \\
\hline 0 to $3 \mathrm{wk}^{\mathrm{b}}$ & .56 & .60 & .60 & .59 & .02 \\
\hline 0 to final ${ }^{\mathrm{c}}$ & .64 & .63 & .68 & .65 & .01 \\
\hline \multicolumn{6}{|c|}{ Average daily feed, $\mathrm{kg}$} \\
\hline 0 to $3 \mathrm{wk}$ & 1.19 & 1.22 & 1.19 & 1.21 & .01 \\
\hline 0 to final & 2.20 & 2.16 & 2.23 & 2.19 & .04 \\
\hline \multicolumn{6}{|l|}{ Gain:feed } \\
\hline 0 to $3 \mathrm{wk}^{\mathrm{d}}$ & .468 & .496 & .508 & .492 & .009 \\
\hline 0 to final & .293 & .290 & .304 & .300 & .006 \\
\hline
\end{tabular}

${ }^{\mathrm{a}} \mathrm{C} 2=$ control; $4 \mathrm{~B}=4 \%$ blended vegetable oil; $4 \mathrm{~T}=4 \%$ tallow; $4 \mathrm{YG}=4 \%$ yellow grease.

${ }^{\mathrm{b}} \mathrm{C} 2$ vs $4 \mathrm{~B}+4 \mathrm{~T}+4 \mathrm{YG}(P<.05)$.

$\mathrm{c}_{4 \mathrm{~B}}$ vs $4 \mathrm{~T}+4 \mathrm{YG}(P<.01)$.

$\mathrm{d}_{\mathrm{C} 2}$ vs $4 \mathrm{~B}+4 \mathrm{~T}+4 \mathrm{YG}(P<.01)$.

The main effects of temperature and receiving diet are presented in Table 7. Pigs exposed to RNT had an improved $(P<.05)$ ADG for the 0 - to 3 -wk period compared with CON with no difference in ADFI or gain:feed for the same period. Overall there was no effect of RNT on ADG, ADFI, or gain:feed.

When pooled across experiments, pigs fed $4 \mathrm{~T}$ or $4 \mathrm{~B}$ receiving diets had improved $(P<.05) \mathrm{ADG}$ and gain: feed for the 0- to 3 -wk period compared with $\mathrm{C} 2$ diets. Overall, pigs fed $4 \mathrm{~T}$ diets vs $4 \mathrm{~B}$ diets were heavier ( $P$ $<.005$ ) with an improved ADG and no difference in gain:feed.

Digestibilities of DM and $\mathrm{N}$ determined by chromic oxide indicator method were not different among the diets at wk 1 or 2 in either experiment (Table 8). However, it is interesting that DM and $\mathrm{N}$ digestibilities in Exp. 2 and $N$ digestibilities in Exp. 3 increased from wk 1, when the pigs were limit fed, to wk 2 when pigs were given ad libitum to access feed.

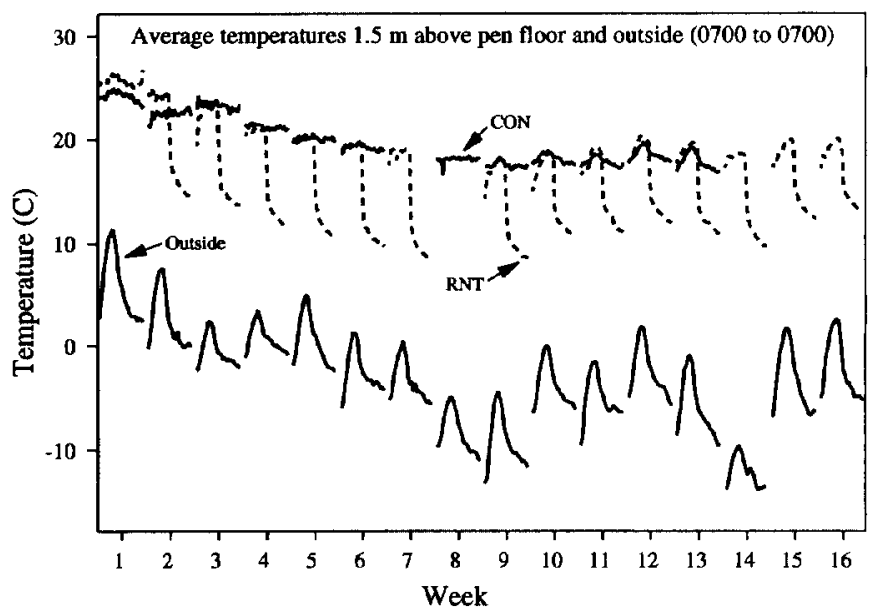

Figure 1. Mean weekly air temperatures by hour of the day at animal level $(\mathrm{CON}=$ control; $\mathrm{RNT}=$ reduced nocturnal temperatures) and outside, Exp. 2 and 3 . 
Table 6. Interaction of temperature and receiving diet on overall feeder pig performance (Exp. 2 and 3 )

\begin{tabular}{|c|c|c|c|c|c|c|c|c|}
\hline \multirow[b]{3}{*}{ Item } & \multirow[b]{3}{*}{ Diet: $^{\mathrm{a}}$} & \multicolumn{6}{|c|}{ Temperature } & \multirow[b]{3}{*}{ SEM } \\
\hline & & \multicolumn{3}{|c|}{$\mathrm{CON}^{\mathrm{b}}$} & \multicolumn{3}{|c|}{$\mathrm{RNT}^{\mathrm{b}}$} & \\
\hline & & $\mathrm{C} 2$ & $4 \mathrm{~T}$ & $4 B$ & $\mathrm{C} 2$ & $4 \mathrm{~T}$ & $4 \mathrm{~B}$ & \\
\hline Average daily gain ${ }^{\text {cd }}$ & & .68 & .69 & .66 & .64 & .68 & .64 & $<.01$ \\
\hline Average daily feed ${ }^{e}$ & & 2.24 & 2.26 & 2.17 & 2.14 & 2.18 & 2.11 & .05 \\
\hline Gain:feed & & .302 & .306 & .302 & .299 & .310 & .303 & .005 \\
\hline
\end{tabular}

${ }^{\mathrm{a}} \mathrm{C} 2=$ control; $4 \mathrm{~T}=4 \%$ tallow; $4 \mathrm{~B}=4 \%$ blended vegetable oil.

${ }^{\mathrm{b}} \mathrm{CON}=$ control; $\mathrm{RNT}=$ reduced nocturnal temperature beginning $1 \mathrm{wk}$ after arrival.

cTemperature $\times$ diet $(P<.05)$.

$\mathrm{d}_{4 \mathrm{~T}}$ vs $4 \mathrm{~B}(P<.001)$.

eTemperature effect $(P<.075)$.

\section{Discussion}

In all three experiments, the addition of fat to the receiving diet, regardless of the source, resulted in increased ME intake for the 0 - to 3-wk period. In their review of the literature regarding fat additions to growing-finishing swine diets, Pettigrew and Moser (1991) suggested that diets containing added fat move through the gastrointestinal tract more slowly, improving the digestion of carbohydrates and protein. Daily gain was reported to improve with up to $5 \%$ added fat with a corresponding reduction in ADFI. No such effect was found in Exp. 2 or 3 (Table 8). The daily gain response for the 0 - to 3-wk period, when the experimental diets contained added fat, was inconsistent with no reductions in ADFI compared with control diets. As expected, gain:feed tended to improve while the fat-containing diets were offered.

The differential positive results on overall ADG for $\mathrm{T}$ containing diets in each experiment was not expected. Stahly (1984), in a discussion of fat response mechanism's for growing pigs, made no mention of long-term responses from short-term feeding of diets containing added tallow. Patterson (1991) reported that the source of fat (tallow or soybean oil) did not differ in their effects on pig performance.

Normally, it is thought that pigs adjust their voluntary food intake to achieve a constant energy intake (Owen and Ridgman, 1967, 1968). In these experiments, energy intake increased for the 3 -wk receiving period because there was no depression in intake for any of the fat supplemented diets compared with the control diets. Brumm et al. (1985), Brumm and Shelton (1988, 1991), and Nienaber and Hahn (1989) have all reported that a reduced nocturnal temperature regimen results in increased feed disappearance (i.e., intake) for nursery pigs. Filmer and Curron (1985) suggest that energy intake increased with reduced temperatures. Holmes and

Table 7. Effect of fat source and reduced nocturnal temperature on feeder pig performance (Exp. 2 and 3)

\begin{tabular}{|c|c|c|c|c|c|c|c|}
\hline \multirow[b]{2}{*}{ Item } & \multicolumn{3}{|c|}{ Diet $^{\mathrm{a}}$} & \multirow[b]{2}{*}{ SEM } & \multicolumn{2}{|c|}{ Temperature $^{\mathrm{b}}$} & \multirow[b]{2}{*}{ SEM } \\
\hline & $\mathrm{C} 2$ & $4 \mathrm{~T}$ & $4 \mathrm{~B}$ & & CON & RNT & \\
\hline No. of pens & 8 & 8 & 8 & - & 12 & 12 & - \\
\hline \multicolumn{8}{|l|}{ Pig wt, kg } \\
\hline Initial & 19.6 & 19.5 & 19.6 & .1 & 19.7 & 19.5 & .1 \\
\hline $3 \mathrm{wk}^{\mathrm{cd}}$ & 31.2 & 32.1 & 32.0 & .2 & 31.8 & 31.9 & .1 \\
\hline Final $^{\mathrm{ce}}$ & 95.4 & 98.3 & 94.3 & .2 & 97.3 & 94.7 & .5 \\
\hline \multicolumn{8}{|c|}{ Average daily gain, $\mathrm{kg}$} \\
\hline 0 to $3 \mathrm{wk}^{\mathrm{cd}}$ & .55 & .60 & .59 & .01 & .56 & .60 & $<.01$ \\
\hline 0 to final $^{\mathrm{e}}$ & .66 & .68 & .65 & $<.01$ & .67 & .65 & .01 \\
\hline \multicolumn{8}{|c|}{ Average daily feed, kg } \\
\hline 0 to $3 \mathrm{wk}$ & 1.20 & 1.23 & 1.20 & .02 & 1.19 & 1.23 & .03 \\
\hline 0 to final $^{f}$ & 2.19 & 2.22 & 2.14 & .03 & 2.22 & 2.15 & .01 \\
\hline \multicolumn{8}{|l|}{ Gain:feed } \\
\hline 0 to $3 \mathrm{wk}^{\mathrm{c}}$ & .460 & .487 & .495 & .008 & .473 & .489 & .011 \\
\hline 0 to final & .300 & .308 & .302 & .004 & .303 & .304 & .001 \\
\hline
\end{tabular}

${ }^{\mathrm{a}} \mathrm{C} 2=$ control; $4 \mathrm{~T}=4 \%$ tallow; $4 \mathrm{~B}=4 \%$ blended vegetable oil.

${ }^{\mathrm{b}} \mathrm{CON}=$ control; $\mathrm{RNT}=$ reduced nocturnal temperature beginning $1 \mathrm{wk}$ after arrival.

${ }^{c} \mathrm{C} 2$ vs $4 \mathrm{~T}+4 \mathrm{~B}(P<.05)$.

d CON vs RNT $(P<.05)$.

$\mathrm{e}_{4 \mathrm{~T}}$ vs $4 \mathrm{~B}(P<.005)$.

$\mathrm{f}_{\mathrm{CON}}$ vs RNT $(P<.075)$. 
Table 8. Apparent digestibilities of dry matter and $\mathrm{N}$ in receiving diets (Exp. 2 and 3)

\begin{tabular}{|c|c|c|c|c|c|c|c|c|}
\hline \multirow{2}{*}{$\begin{array}{l}\text { Experiment, } \\
\text { item, and } \\
\text { period, d }\end{array}$} & \multicolumn{7}{|c|}{$\operatorname{Diet}^{\mathrm{a}}$} & \multirow[b]{2}{*}{ SEM } \\
\hline & $\mathrm{C} 2$ & $2 B$ & $4 \mathrm{~B}$ & $6 \mathrm{~B}$ & $4 \mathrm{~T}$ & $4 \mathrm{SO}$ & $4 Y G$ & \\
\hline 2 & \multicolumn{7}{|c|}{ - \% Digestibility } & \\
\hline \multicolumn{9}{|l|}{ Dry matter } \\
\hline $5,6,7$ & 76.6 & 80.5 & 72.6 & 80.2 & 77.7 & 79.1 & - & 2.3 \\
\hline $12,13,14$ & 78.6 & 83.4 & 78.2 & 80.8 & 79.6 & 81.2 & - & 1.8 \\
\hline \multicolumn{9}{|l|}{ Nitrogen } \\
\hline $5,6,7$ & 66.1 & 74.8 & 61.1 & 72.8 & 66.9 & 71.3 & - & 3.3 \\
\hline $12,13,14$ & 71.8 & 80.0 & 70.5 & 74.8 & 71.5 & 73.0 & - & 2.5 \\
\hline \multicolumn{9}{|l|}{3} \\
\hline \multicolumn{9}{|l|}{ Dry matter } \\
\hline $5,6,7$ & 81.3 & - & 78.6 & - & 78.5 & - & $73.5^{\mathrm{b}}$ & 2.2 \\
\hline $12,13,14$ & 79.8 & - & 78.8 & - & 77.7 & - & 76.5 & 1.8 \\
\hline \multicolumn{9}{|l|}{ Nitrogen } \\
\hline $5,6,7$ & 75.6 & - & 73.0 & - & 72.2 & - & $64.5^{\mathrm{b}}$ & 3.4 \\
\hline $12,13,14$ & 77.4 & - & 75.4 & - & 77.0 & - & 73.0 & 2.0 \\
\hline
\end{tabular}

${ }^{\mathrm{a}} \mathrm{C} 2=$ control; $2 \mathrm{~B}=2 \%$ blended vegetable oil; $4 \mathrm{~B}=4 \%$ blended vegetable oil; $6 \mathrm{~B}=6 \%$ blended vegetable oil; $4 \mathrm{~T}=4 \%$ tallow; $4 \mathrm{SO}=4 \%$ soybean oil; $4 \mathrm{YG}=4 \%$ yellow grease.

bIncludes only four replications vs six for all other means.

Close (1985) suggest that the lower critical temperature, below which feed intake is increased, for grouphoused pigs on solid floors weighing $60 \mathrm{~kg}$ is between $13^{\circ}$ and $18^{\circ} \mathrm{C}$. These references suggested that the RNT treatment should have been effective in stimulating feed disappearance when in fact, disappearance was less than CON (Table 7).

The general increase in $\mathrm{DM}$ and $\mathrm{N}$ apparent digestibilities between wk 1 (limit fed) and wk 2 (ad libitum offering) was unexpected: Maynard and Loosli (1969) suggested limit-fed nonruminants have improved nutrient digestibilities. In these experiments, the variation in $\mathrm{DM}$ and $\mathrm{N}$ digestibilities within fat sources was considerable and no conclusion is possible about differences between fat sources or fat inclusion levels.

\section{Implications}

These results suggest that the commingled feeder pig responds to receiving diets containing tallow in a positive manner to slaughter. However, the response was not evident for soybean oil or vegetable blend fat sources. It is not known whether this response is dependent on the unique physiological state of the commingled feeder pigs used in these experiments. Unlike the newly-weaned pig, reduced nocturnal temperatures resulted in a depression in overall average daily feed intake when imposed from 1 wk after arrival to slaughter. Thus, its use is not recommended as a management tool to improve growing-finishing pig performance. These results also do not support the use of the feed flavor investigated to stimulate feed intake of commingled feeder pigs.

\section{Literature Cited}

AOAC. 1990. Official methods of analysis (15th Ed.). Association of Official Analytical Chemists, Arlington, VA.

Brumm, M. C., M. Y. Ash, G. W. Jesse, and W. G. Luce. 1991. Starting purchased feeder pigs. Coop. Ext. Service Publ. No. PIH-20 (Rev.). Purdue Univ., West Lafayette, IN.

Brumm, M. C., G. W. Jesse, H. F. Mayes, and E. T. Clemens. 1989. Effects of feed or water restriction, antibiotic injection and receiving diet management on commingled feeder pig performance. J. Anim. Sci. 67:1183.

Brumm, M. C., G. W. Jesse, H. F. Mayes, G. M. Zinn, and E. T. Clemens. 1987. Effects of feed and water restriction and receiving diet crude protein on feeder pig performance. J. Anim. Sci. 64:1606.

Brumm, M. C., E. R. Peo, Jr., S. R. Lowry, and A. Hogg. 1982. Effect of source of pig, housing system and receiving diet on performance of purchased feeder pigs. J. Anim. Sci. 55:1264.

Brumm, M. C., and D. P. Shelton. 1988. A modified reduced nocturnal temperature regimen for early-weaned pigs. J. Anim. Sci. 66:1067.

Brumm, M. C., and D. P. Shelton. 1991. Two reduced nocturnal temperature regimens for early-weaned pigs. J. Anim. Sci. 69: 1379 .

Brumm, M. C., D. P. Shelton, and R. K. Johnson. 1985. Reduced nocturnal temperatures for early weaned pigs. J. Anim. Sci. 61: 552.

Filmer, D. G., and M. K. Curran. 1985. Climatic environment and practical nutrition of the growing pig. In: D.J.A. Cole and W. Haresign (Ed.) Recent Developments in Pig Nutrition. p 41. Butterworths, Boston, MA.

Holmes, C. W., and W. H. Close. 1985. The influence of climatic variables on energy metabolism and associated aspects of productivity in the pig. In: D.J.A. Cole and W. Haresign (Ed.) Recent Developments in Pig Nutrition. $p$ 18. Butterworths, Boston, MA.

Maynard, L. A., and J. K. Loosli. 1969. Animal Nutrition (6th Ed.). McGraw-Hill, New York.

NRC. 1988. Nutrient Requirements of Swine (9th Ed.). National Academy Press, Washington, DC.

Nienaber, J. A., and G. L. Hahn. 1989. Cool nighttime temperature and weaning age effects on 3 to 10 week old pigs. Trans. Am. Soc. Agric. Eng. 32:691.

Owen, J. B., and W. J. Ridgman. 1967. The effect of dietary energy 
content on the voluntary intake of pigs. Anim. Prod. 9:107.

Owen, J. B., and W. J. Ridgman. 1968. Further studies on the effect of dietary energy content on the voluntary intake of pigs. Anim. Prod. 10:85.

Patterson, D. C. 1991. Effect of concentration and blend of added fat in the diet on the performance of growing pigs. J. Agric. Sci. 116:11.

Pettigrew, J. E., and R. L. Moser. 1991. Fat in swine nutrition. In: E. R. Miller, D. E. Ullrey, and A. J. Lewis (Ed.) Swine Nutrition. p 133. Butterworth-Heineman, Boston, MA.
SAS. 1982. SAS User's Guide. SAS Inst. Inc., Cary, NC.

Schürch, A. F., E. W. Crampton, S. R. Haskell, and L. E. Lloyd. 1952. The use of chromic oxide in digestibility studies with pigs fed ad libitum in the barn. J. Anim. Sci. 11:261.

Shelton, D. P., and D. D. Schulte, 1982. Vented and unvented furnaces for swine housing. In: D. E. Bundy (Ed.) Livestock Environment II. p 216. Am. Soc. Agric. Eng., St. Joseph, MI.

Stahly, T. S. 1984. Use of fats for growing pigs. In: J. Wiseman (Ed.) Fats in Animal Nutrition. p 313. Butterworths, Boston, MA. 